\title{
HUBUNGAN KUALITAS TIDUR DENGAN JENIS NYERI KEPALA PRIMER PADA SISWA-SISWI SMA NEGERI 1 PADANG
}

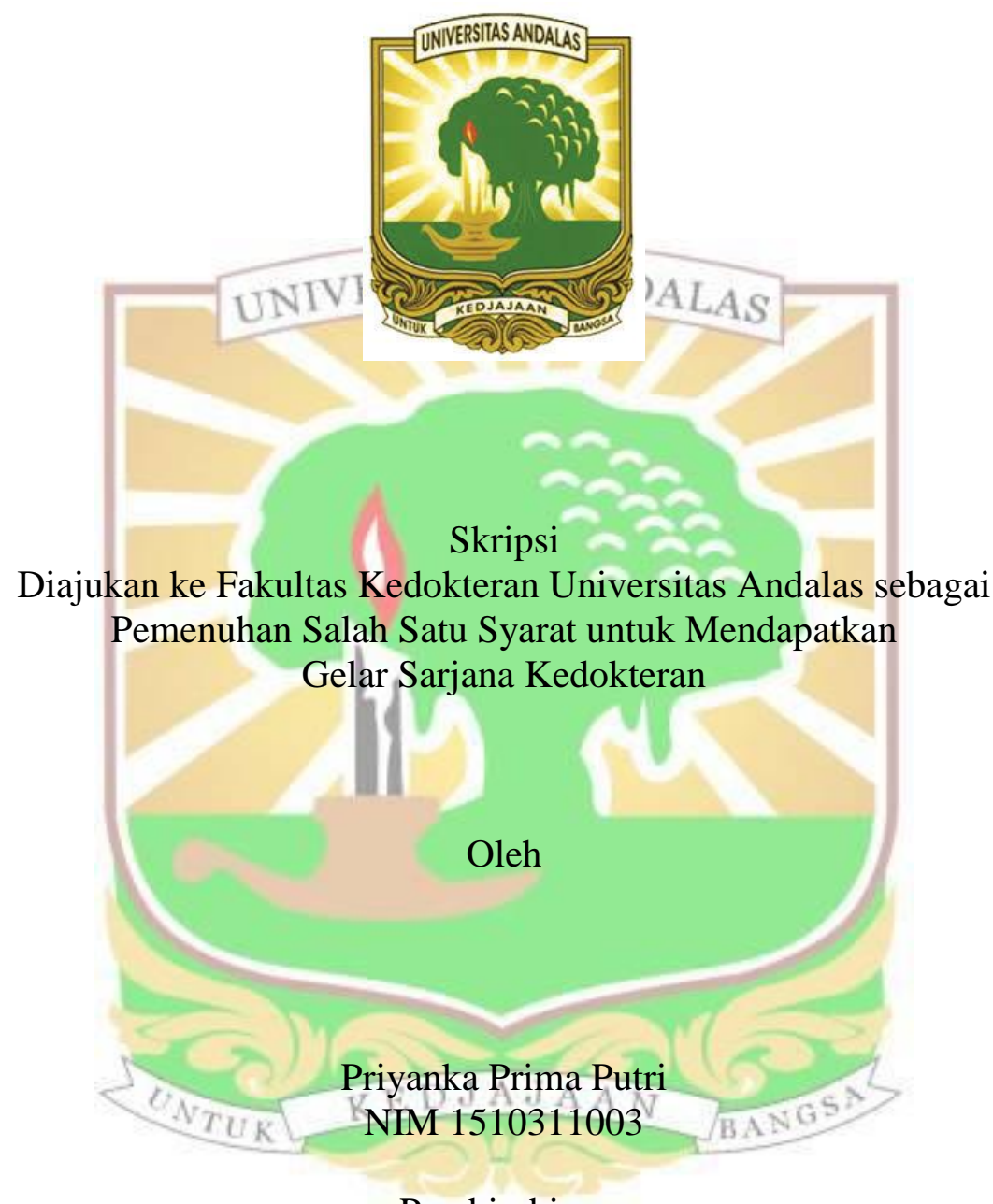

Pembimbing:

1. dr. Restu Susanti, Sp. S, M. Biomed

2. Dr. Gusti Revilla, M.Kes

\author{
FAKULTAS KEDOKTERAN \\ UNIVERSITAS ANDALAS \\ PADANG \\ 2020
}




\title{
RELATIONSHIP BETWEEN SLEEP QUALITY AND THE TYPE OF PRIMARY HEADACHE IN SMA NEGERI 1 PADANG STUDENTS
}

\author{
By \\ Priyanka Prima Putri
}

\begin{abstract}
Primary headache is the most common complain found in adolescents. Primary headache can be triggered by several factors, one of them is bad sleep quality. Both are the most experienced problems in adolescents that can decrease productivity academically and non-academically in schools. The aim of this study was to detemine the relationship between sleep quality and the type of primary headache in students of SMA Negeri 1 Padang.

This study was analytic study with cross sectional design. The sampling was done by purposive sampling technique and obtained 90 sampels. The diagnosis of primary headache is based on the headahe consensus of PERDOSSI 2018 which is corresponding with 3rd Edition of International Classification of Headache Disorder (Beta version). The data of sleep quality was collected by using The Pittsburgh Sleep Quality Index questionnaire. The data was analyzed by using Chi Square test.

The results showed that the majority of respondents were women $(70 \%)$. The most common sleep quality was poor $(67.8 \%)$. The most common type of headache is tension-type headache $(78.9 \%)$ and migraines $(21.1 \%)$. There was a significant relationship between sex and sleep quality with low correlation ( $p<0.001$ and $r=0.396$ ). There is no relationship between sex with the type of primary headache. There was a significant relationship between sleep quality and the type of primary headache that is tension type headache with moderate correlation ( $\mathrm{p}<0.001$ and $\mathrm{r}=0.454)$ and migraine with low correlation $(\mathrm{p}=0.022$ and $r=0.311$ ). Based on this study, it can be concluded that bad sleep quality will increase the probability of suffering primary headache.
\end{abstract}

Keywords: Sleep quality, primary headache, adolescents 


\title{
HUBUNGAN KUALITAS TIDUR DENGAN JENIS NYERI KEPALA PRIMER PADA SISWA-SISWI SMA NEGERI 1 PADANG
}

\author{
Oleh \\ Priyanka Prima Putri
}

\begin{abstract}
ABSTRAK
Nyeri kepala primer merupakan keluhan yang sering dijumpai pada remaja. Nyeri kepala primer dipicu oleh beberapa faktor, salah satunya adalah kualitas tidur yang buruk. Keduanya merupakan masalah yang sering dialami remaja yang dapat menurunkan produktivitas akademik dan non-akademik di sekolah. Tujuan dari penelitian ini adalah untuk mengetahui apakah terdapat hubungan antara kualitas tidur dengan nyeri kepala primer pada siswasiswi SMA Negeri 1 Padang.

Jenis penelitian ini adalah penelitian analitik dengan desain cross sectional. Pengambilan sampel dilakukan dengan teknik purposive sampling dan didapatkan sampel sebanyak 90 sampel. Diagnosis nyeri kepala primer berdasarkan konsensus nyeri kepala PERDOSSI tahun 2018 yang sesuai dengan International Classification of Headache Disorder Edisi 3 (versi beta). Data kualitas tidur dikumpulkan menggunakan kuesioner The Pittsburgh Sleep Quality Index. Analisis data menggunakan uji Chi Square.

Hasil penelitian menunjukkan sebagian besar responden adalah perempuan (70\%). Kualitas tidur terbanyak yaitu buruk $(67,8 \%)$. Jenis nyeri kepala primer terbanyak adalah nyeri kepala tipe tegang $(78,9 \%)$ dan migrain $(21,1 \%)$. Terdapat hubungan yang bermakna antara jenis kelamin dengan kualitas tidur dengan korelasi lemah $(\mathrm{p}<0,001$ dan $\mathrm{r}=0,396)$. Tidak terdapat hubungan antara jenis kelamin dengan jenis nyeri kepala primer. Terdapat hubungan yang bermakna antara kualitas tidur dengan jenis nyeri kepala primer yaitu nyeri kepala tipe tegang dengan korelasi sedang $(\mathrm{p}<0,001$ dan $\mathrm{r}=0,454)$ dan migrain dengan korelasi lemah $(\mathrm{p}=0,022$ dan $=0,311)$. Berdasarkan penelitian ini dapat disimpulkan bahwa kualitas tidur buruk akan meningkatkan kemungkinan mengalami nyeri kepala primer.
\end{abstract}

Kata kunci : Kualitas tidur, nyeri kepala primer, remaja 